\title{
Rевеавсн Автісік: Effect of integrated plant nutrition system on yield and uptake of cotton under soil test crop response correlation studies through drip fertigation on inceptisol
}

S. PRAVEENA KATHARINE, R. SANTHI, S. MARAGATHAM AND PRADIP DEY

ArTiCle Chronicle: Received :

11.07.2017;

Accepted :

26.07.2017

KEY WoRds:

Soil test crop response, Integrated plant nutrition system, Yield target, Fertilizer prescriptions, Nutrient contribution

Author for correspondence :

\section{S. PRAVEENA}

\section{KATHARINE}

Agricultural Engineering College and Research Institute, KUMULUR (T.N.) INDIA

See end of the article for authors' affiliations
SUMMARY : Studies on Soil Test Crop Response based Integrated Plant Nutrition System (STCR IPNS)were conducted during 2011-13 adopting the Inductive cum Targeted yield model, on a Vertic Ustropept soil of Tamil Nadu, South India in order to develop fertilizer prescriptions for the desired yield targets of transgenic cotton through drip fertigation. The basis for making the fertilizer prescriptions viz., nutrient requirement (NR), contribution of nutrients from soil (Cs), fertilizer (Cf) and farmyard manure (Cfym) were computed using the field experimental data. Making use of these basic parameters, the fertilizer prescription equations were developed under NPK alone and IPNS for the desired yield targets of cotton for a range of soil test values. When applied along with the NPK fertilizers as per soil test and desired yield target, the quantity of nutrients that could be contributed by the application of farmyard manure (FYM) @ $12.5 \mathrm{tha}^{-1}$ (with $32 \%$ moisture, $0.64,0.31$ and $0.61 \%$ of N, P and K, respectively) for cotton was assessed as 40,20 and $34 \mathrm{~kg}$ fertilizer $\mathrm{N}, \mathrm{P}_{2} \mathrm{O}_{5}$ and $\mathrm{K}_{2} \mathrm{O}$, respectively, The per cent reduction in fertilizer $\mathrm{N}, \mathrm{P}_{2} \mathrm{O}_{5}$ and $\mathrm{K}_{2} \mathrm{O}$ requirement under IPNS increased with increasing soil available NPK status.

How to cite this article : Katharine, S. Praveena, Santhi, R., Maragatham, S. and Dey, Pradip (2017). Effect of integrated plant nutrition system on yield and uptake of cotton under soil test crop response correlation studies through drip fertigation on inceptisol. Agric. Update, 12 (TECHSEAR-4): 1028-1036; DOI: 10.15740/HAS/AU/ 12.TECHSEAR (4)2017/1028-1036. 